\title{
Pengaruh CR dan EPS terhadap Harga Saham pada Perusahaan Farmasi di BEI Periode 2015-2018
}

\author{
Amalia Rona Hamzah \\ Universitas Singaperbangsa Karawang \\ Karawang, Indonesia \\ dailibas@fe.unsika.ac.id
}

Corresponding Author: Amalia Rona Hamzah

Submitted: 20 Juli 2020

Accepted: 30 Agustus 2020

Published: 30 Agustus 2020

\begin{abstract}
ABSTRAK
Penelitian ini bertujuan untuk menganalisis pengaruh variabel mengetahui Current Ratio dan Earning Per Share secara parsial maupun simultan Terhadap Harga Saham perusahaan farmasi yang terdaftar di Bursa Efek Indonesia periode 2015 sampai 2018. Penelitian ini merupakan jenis penelitian deskriptif kuantitatif, yang menggunakan data dari 10 perusahaan farmasi yang terdaftar di Bursa Efek Indonesia. Metode pengambilan sampel yang digunakan dalam penelitian ini adalah Purposive sampling dan diperoleh sampel sebanyak 8 sampel. Data yang digunakan adalah laporan keuangan dari masing-masing perusahaan sampel yang di publikasikan melalui situs www.idx.co.id. Adapun variabel yang berkaitan dalam penelitian ini adalah Current Ratio dan Earning Per Share. Metode penelitian yang digunakan adalah metode analisis deskriptif. Hasil penelitian menunjukan bahwa secara parsial Current Ratio berpengaruh positif dan signifikan terhadap Harga Saham, sedangkan Earning Per Share tidak berpengaruh negatif dan tidak signifikan terhadap Harga Saham pada perusahaan farmasi yang terdaftar di Bursa Efek Indonesia. Hasil penelitian lain juga menunjukan bahwa secara simultan Current Ratio, dan Earning per Share secara bersama-sama berpengaruh signifikan terhadap Harga Saham yang terdaftar di Bursa Efek Indonesia periode 2015-2018.
\end{abstract}

\section{Kata kunci: Current Ratio, Earning Per Share, Harga Saham}

\section{PENDAHULUAN}

Pasar modal mempunyai peranan penting dalam menunjang perkonomian suatu negara, dan suatu sarana yang baik di manfaatkan untuk memobilisisasi dana baik dari dalam maupun luar negri. Pasar Modal pada hakekatnya adalah pasar yang tidak berbeda jauh dengan pasar tradisional yang selama ini kita kenal, di mana ada pedagang, pembeli, dan juga tawar me-nawar harga. Pasar modal dapat juga diartikan sebagai sebuah wahana yang mempertemukan pihak yang membutuhkan dana dengan pihak yang menyediakan dana sesuai dengan aturan yang ditetapkan oleh lembaga dan profesi yang berkaitan dengan efek. Perusahaanperusahaan harus menjalin kerja sama yang erat untuk menciptakan pasar yang mampu menyediakan berbagai jenis produk dan alternatif investasi bagi masyarakat. 
Harga saham mencerminkan nilai suatu perusahaan. Jika perusahaan mencapai nilai yang baik, maka nilai saham perusahaan dapat dilihat dari laporan keuangan yang dipublikasikan oleh perusahaan. Perusahaan berkewajiban untuk mempublikasikan laporan keuangan pada waktu periode tertentu. Laporan keuangan ini sangat berguna bagi investor untuk pengambilan investasi. Harga saham di bursa tidak selamanya tetap, adakalanya meningkat dan bisa pula menurun, tergantung pada kekuatan permintaan dan penawarannya. Di pasar modal, terjadinya fluktuasi harga saham tersebut menjadikan bursa efek menarik bagi beberapa kalangan pemodal (investor).

Biasanya salah satu faktor yang mempengaruhi penurunan harga saham adalah kinerja keuangan. Kinerja keuangan adalah gambaran kondisi keuangan perusahaan pada suatu periode tertentu baik menyangkut aspek penghimpunan dana maupun penyaluran dana, yang biasanya diukur dengan indikator kecukupan modal, likuiditas, dan profitabilitas.

Current Ratio (CR) adalah ratio yang menilai tingkat likuiditas perusahaan, rasio likuiditas merupakan salah satu faktor yang dapat mendorong terjadi perubahan harga saham. Dalam Current Ratio ini akan diketahui sejauh mana aktiva lancar perusahaan dapat digunakan untuk menutupi kewajiban jangka pendek atau utang lancarnya. Aktiva lancar biasanya berupa: kas, surat berharga, piutang, dan persediaan. Hutang lancar terdiri dari hutang dagang, wesel bayar jangka pendek, hutang jangka panjang yang segera jatuh tempo, pajak yang belum dibayar, biaya-biaya yang belum dibayar.

Earning Per Share. Ratio tersebut adalah ratio profitabilitas. Profitabilitas merupakan kemampuan perusahaan untuk menghasilkan laba dengan menggunakan sumber-sumber yang dimiliki perusahaan, seperti aktiva, modal atau penjualan (Sudana, 2018). EPS atau yang disebut juga sebagai laba per lembar saham merupakan ratio keuangan yang mengukur suatu jumlah laba bersih yang diperoleh per lembar saham yang beredar. Semakin banyak jumlah saham yang beredar maka akan mempengaruhi tingkat atau besar laba per lembarnya. Karena, keuntungan perusahaan akan dibagikan ke seluruh lembar saham yang diterbitkan oleh perusahaan yang bersangkutan. Jadi, tingginya laba per lembar saham pada suatu perusahaan tidak selalu menunjukan kinerja lebih baik dibandingkan dengan perusahaan lain. Karena tinggi rendahnya tingkat per lembar saham dipengaruhi oleh jumlah saham yang beredar.

Beberpa penelitian telah dilakukan agar membuktikan pengaruh Current Ratio dan Earning Per Share terhadap Harga saham. Pada penelitian yang sudah dilakukan oleh (Widodo \& Dewi, 2017) dengan judul "Pengaruh CR, DER dan EPS Terhadap Harga Saham di BEI" menunjukan bahwa CR, DER dan EPS secara simultan berpengaruh signifikan terhadap harga saham. Namun bertentangan dengan hasil penelitian yang dilakukan oleh Pande Widya Rahmadewi dan Nyoman Abundanti yang berjudul "Pengaruh EPS, PER, CR, dan ROE Terhadap Harga Saham di BEI" menunjukan bahwa hasil secara parsial EPS,CR, DAN ROE berpengaruh negatif terhadap harga saham. Penelitian (Wilda, Kardinal, \& Elisabeth, 2015) tentang pengaruh ROE, CR, dan EPS terhadap harga saham pada perusahaan makanan dan minuman yang terdaftar di BEI, menunjukan bahwa CR dan EPS berpengaruh secara parsial terhadap harga saham.

\section{TINJAUAN PUSTAKA \\ 2.1. Teori Pengaruh Current Ratio terhadap Harga Saham}


Rasio lancar atau Current Ratio merupakan rasio untuk mengukur kemampuan perusahaan dalam membayar kewajiban mengukur kemampuan perusahaan dalam membayar kewajiban jangka pendek atau utang yang segera jatuh tempo pada saat ditagih secara keseluruhan. Dengan kata lain, seberapa banyak aktiva lancar tersedia untuk menutupi kewajiban jangka pendek yang segera jatuh tempo (Kasmir, 2015).

Rasio lancar mengukur kemampuan perusahaan memenuhi utang jangka pendeknya dengan menggunakan aktiva lancarnya (aktiva yang akan berubah menjadi kas dalam waktu untuk satu tahun atau satu siklus bisnis (Mahmud, 2016).

\subsubsection{Indikator Current Ratio terhadap Harga Saham}

Ratio ini biasanya digunakan untuk mengukur besar uang kas yang tersedia untuk melunasi kewajiban jangka pendek yang ditunjukan dari tersedianya dana kas atau setara kas (Sutrisno, 2016).

Current Ratio $=\underline{\text { Aktifa Lancar }}$

$$
\text { Utang Lancar }
$$

\subsection{Teori Pengaruh Earning Per Share terhadap Harga Saham}

Menurut (Martani, 2016) Laba Per Saham merupakan informasi mengenai berapa jumlah laba yang dapat diatribusikan kepada pemegang saham biasa per lembarnya.

Keuntungan yang diberikan kepada pemegang saham untuk tiap lembar saham yang dipegangnya (Fahmi, 2016)

Earning Per Share adalah jumlah pendapatan yang diperoleh dalam satu periode untuk tiap lembar saham yang beredar. Informasi mengenai Earning Per Share dapat digunakan oleh perusahaan dalam menentukan dividen yang akan dibagikan. Informasi tersebut juga berguna bagi investor untuk mengetahui perkembangan perusahaan (Baridwan, 2013).

\subsubsection{Indikator Earning Per Share terhadap Harga Saham \\ Earning Per Share (EPS)} merupakan rasio yang menunjukkan bagian laba pada setiap sahamnya (Darmadji, Tjiptono, \& Fakhrudidin, 2016).

\section{EPS $=$ Laba Bersih tembar Saham yang Beredar}

\subsection{Pengertian Harga Saham}

Harga yang terjadi di pasar bursa pada saat tertentu yang ditentukan oleh pelaku pasar dan ditentukan oleh permintaan dan penawaran saham yang bersangkutan di pasar modal (Hartono, 2016).

Pembentukan harga saham terjadi karena adanya permintaan dan penawaran atas saham tersebut. Dengan kata lain, harga saham terbentuk oleh supply dan demand harga saham tersebut (Martalena \& Maya Melinda, 2015)

Menyatakan bahwa Harga saham merupakan harga jual dari suatu saham yang tercatat di bursa efek dan digunakan sebagai indikator penting untuk mengetahui kinerja manajemen dalam mengelola perusahaan.

\subsection{Kerangka Pemikiran}

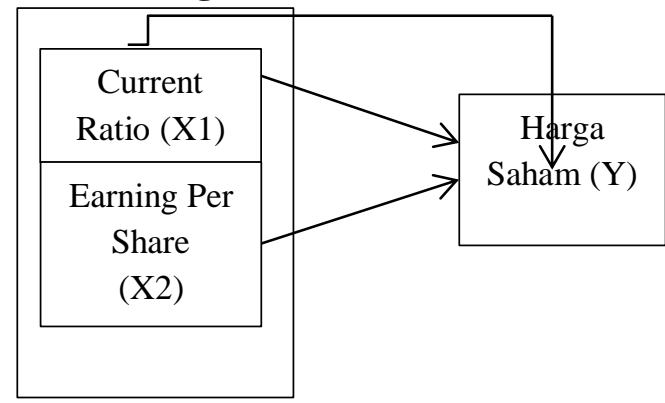

\subsection{Hipotesis Penelitian}

Hipotesis merupakan jawaban sementara terhadap rumusan masalah yang menyatakan hubungan antara dua variabel atau lebih. Adapun hipotesis dalam penelitian ini adalah sebagai berikut: 
H1: Ada pengaruh Current Ratio terhadap harga saham pada perusahaan farmasi yang terdaftar di BEI periode 2015-2018.

H2: Ada pengaruh Earning Per Share terhadap harga saham pada perusahaan farmasi yang terdaftar di BEI periode 2015-2018.

H3: Ada pengaruh Current Ratio dan Earning Per Share terhadap harga saham pada perusahaanfarmasi yang terdaftar di BEI periode 2015-2018.

\section{METODE PENELITIAN}

Metode yang digunakan dalam penelitian ini adalah metode kuantitatif. Metode kuantitatif menurut (Sugiyono, 2015) adalah metode penelitian yang berdasarkan pada filsafat positivisme yang digunakan pada populasi atau sampel tertentu, pengumpulan data menggunakan instrument penelitian kuantitatif atau statistik.

Pendekatan dalam penelitian ini yaitu menggunakan metode kuantitatif. Secara umum, metode kuantitatif merupakan prosedur penelitian yang dilakukan dengan cara mengumpulkan dan menganalisa data secara sistematis guna mengetahui hubungan sebab akibat antara dua variabel atau lebih.

\subsection{Variabel Penelitian}

Variabel adalah suatu atribut atau sifat atau nilai dari orang, objek, atau kegiatan yang mempunyai variabel tertentu yang ditetapkan oleh peneliti untuk dipelajari atau ditarik kesimpulannya (Sugiyono, 2015).

Variber dependen dalam penelitian ini adalah harga saham. Harga saham yang digunakan adalah harga penutupan (closing price) yaitu transaksi pada akhir Desember dari investasi saham.

Variabel independen pada penelitian ini adalah Current Ratio, Earning Per Share. Variabel bebas atau independen adalah variabel yang mempengaruhi variabel lain. Variabel bebas merupakan variabel yang mempengaruhi atau yang menjadi sebab perubahannya atau timbulnya variabel dependen (terikat) (Sugiyono, 2015).

\subsection{Populasi dan Sampel}

Populasi yang dimaksud dalam penelitian ini adalah seluruh perusahaan farmasi yang terdaftar do BEI.

Sampel dalam penelitian ini adalah 8 perusahaan yang memenuhi kriteria sebagai sampel penelitian yaitu perusahaan yang secara lengakap melaporkan laporan keuangan dari tahun 2015 sampai 2018. Delapan sampel tersebut adalah PT Darya-Varia Laboratoria Tbk, PT Indofarma (Persero) Tbk, PT Kimia Farma (Persero) Tbk, PT Kalbe Farma Tbk, PT Merck Tbk, PT Pyridam Farma Tbk, PT Industri Jamu dan Farmasi Sido Muncul Tbk, PT Tempo Scan Pacific Tbk.

\subsection{Teknik Analisis Data}

\subsubsection{Uji Aanalisis Regresi Linear Berganda}

(Sugiyono, 2015) mengatakan bahwa analisis regresi linear berganda adalah analisi yang digunakan peneliti, bila mbermaksud meramalkan bagaimana keadaan (naik dan turunnya) variabel independen (kriterium).

Model persamaan regresi linear berganda adalah sebagai berikut:

$\mathrm{Y}=\mathrm{a}+\mathrm{b} 1 \mathrm{X} 1+\mathrm{b} 2 \mathrm{X} 2+\mathrm{e}$

\subsubsection{Uji Asumsi Klasik}

\section{Uji Normalitas}

Uji normalitas ini bertujuan untuk mengetahui distribusi data dalam variabel yang akan digunakan dalam penelitian. Data yang baik dan layak digunakan dalam penelitian adalah data yang memiliki distribusi normal (Sujarweni, 2016).

\section{Uji Multikolinieritas}


Uji multikolinieritas diperlukan untuk mengetahui ada tidaknya variabel independen yang memilii kemiripan antara variabel independen dalam suatu model. Kemiripan antar variabel independen akan mengakibatkan korelasi yang sangat kuat. Selain itu untuk uji ini juga untu menghindari kebiasaan dalam proses pengambilan keputusan mengenai pengaruh pada uji parsial masing- masing variabel independen terhadap variabel dependen.

\section{Uji Heteroskedastisitas}

Uji heterokedastisitas bertujuan untuk menguji terjadinya perbedaan variance residual suatu periode pengamatan ke periode pengamatan yang lain. Jika variance dari residual satu pengamatan ke pengamatan lain tetap maka disebut homokedastisitas dan jika berbeda disebut heteroskedastisitas.

\section{Uji Autokolerasi}

Uji autokolerasi bertujuan untuk menguji apakah suatu model regresi linier ada kolerasi antara kesalahan pada periode $t$ dengan periode $t-1$ (sebelumnya). Jika tidak terjadi autokolerasi maka dinamakan problem autokolerasi (Rochaety, Tresnati, \& Latief, 2019).

\subsubsection{Uji Koefisien Determinasi}

Uji Koefisien Determinasi (Uji $\mathrm{R}^{2}$ ) bertujuan untuk mengukur sejauh mana variabel bebas dapat menjelaskan variasi variabel terikat, baik secara parsial maupun simultan. Nilai koefisien determinasi ini adalah antara nol sampai dengan satu $\left(0<\mathrm{R}^{2}<1\right)$

Menurut (Ghozali, 2018, p. 95) nilai $\mathrm{R}^{2}$ yang kecil mengandung arti bahwa kemampuan variabel bebas dalam menjelaskan variasi variabel terikat sangat terbatas. Sebaliknya, nilai $\mathrm{R}^{2}$ yang hampir mendekati satu mengandung arti bahwa variabel bebas memberikan hampir semua informasi yang dibutuhkan untuk memprediksi variasi-variabel independen.

\subsubsection{Uji Hipotesis \\ 1. Uji t}

Uji statistik $t$ digunakan untuk mengetahui seberapa besar pengaruh masing- masing variabel independen terhadap variabel dependen. Hipotesis akan digunakan dalam penelitian ini berkaitan dengan ada tidaknya pengaruh variabel independen terhadap variabel dependen.

$(\mathrm{H} 0)=$ tidak terdapat pengaruh antara variabel independen terhadap variabel dependen.

(H1) = terdapat pengaruh antara variabel independen terhadap variabel dependen.

Pengujian ini dilakukan untuk mengetahui ada tidaknya pengaruh antara variabel independen (X) yaitu Current Ratio (X1) dan Earning Per Share (X2) secara parsial atau sendiri-sendiri terhadap variabel dependen yaitu Harga Saham (Y). Pengambilan keputusan dilakukan berdasarkan perbandingan nilai thasil perhitungan (thitung) dengan nil ttabel, dengan tingkat signifikan 5\%.

1. Jika nilai thitung $>$ ttabel atau thtung $<$-ttabel maka H0 ditolak dan $\mathrm{H} 1$ diterima, yang berarti variabel independen berpengaruh terhadap nilai variabel dependen.

2. Sedangkan jika nilai -ttabel < thitung < ttabel maka $\mathrm{H} 0$ diterima dan $\mathrm{H} 1$ ditolak, yang berarti variabel independen tidak berpengaruh terhadap nilai variabel dependen (Sujarweni, 2016).

\section{Uji F}

Uji statistic $F$ digunakan untuk mengetahui seberapa besar pengaruh variabel independen secara bersamasama terhadap variabel dependen. 
Hipotesis yang akan digunakan dalam penelitian ini berkaitan dengan ada tidaknya pengaruh variabel independen terhadap variabel dependen.

$\left(\mathrm{H}_{0}\right)=$ tidak terdapat pengaruh antara varibel independen terhadap variabel dependen.

$\left(\mathrm{H}_{1}\right)$ = terdapat pengaruh antara varibel independen terhadap variabel dependen.

Pengujian ini dilakukan untuk menguji ada tidaknya pengaruh antara variabel independen (X) yaitu Current Ratio $\left(\mathrm{X}_{1}\right)$ dan Earning Per Share $\left(\mathrm{X}_{2}\right)$ secara bersama-sama terhadap variabel dependen yaitu Harga Saham (Y). pengambilan keputusan dilakukan berdasarkan perbandingan nilai $F$ perhitungan $\left(F_{\text {hitung }}\right)$ dengan nilai $f_{\text {tabel}}$, dengan tingkat signifikan 5\%.

1. Jika nilai $f_{\text {hitung }}>f_{\text {tabel }}$ maka $H_{0}$ ditolak dan $\mathrm{H}_{1}$ diterima, yang berarti semua variabel independen berpengaruh terhadap nilai variabel dependen.

2. Sedangkan jika nilai $f_{\text {hitung }}<f_{\text {tabel }}$ maka $\mathrm{H}_{0}$ diterima dan $\mathrm{H}_{1}$ ditolak, yang berarti semua variabel independen tidak berpengaruh terhadap nilai variabel dependen.

\section{HASIL DAN PEMBAHASAN}

\subsection{Uji Asumsi Klasik}

\subsubsection{Uji Normalitas}

One-Sample Kolmogorov-Smirnov

\section{Test}

\begin{tabular}{|l|r|}
\hline & $\begin{array}{r}\text { Unstandardized } \\
\text { Residual }\end{array}$ \\
\hline $\mathrm{N}$ & 32 \\
Normal &, 0000000 \\
Parameterrs ${ }^{\mathrm{a}, \mathrm{b}}$ & 6,71753818 \\
Mean &, 139 \\
& .139 \\
Std. Deviation &,- 098 \\
Most Extreme &, 139 \\
Differences &, $118^{\mathrm{c}}$ \\
Absolute & \\
& \\
Positive & \\
& \\
Negative & \\
\hline
\end{tabular}

\begin{tabular}{|l|l|}
\hline Test Statistic & \\
Asymp. Sig. (2- \\
tailed)
\end{tabular}

a. Test distribution is normal

b. Calculated from data

c. Lilliefors Significance Correction

Dari tabel diatas, terlihat bahwa nilai signifikansi yang diperoleh lebih besar dari 0,05 . Hal ini menunjukan bahwa data yang digunakan berdistribusi normal sehingga dapat di katakana bahwa asumsi normalitas data terpenuhi.

\subsubsection{Uji Multikolinieritas}

\section{Coefficients $^{\mathrm{a}}$}

\begin{tabular}{|c|c|c|c|c|c|c|c|}
\hline \multirow[b]{2}{*}{ Model } & \multicolumn{2}{|c|}{$\begin{array}{l}\text { Undstandardized } \\
\text { Coefficients }\end{array}$} & \multirow{2}{*}{$\begin{array}{l}\text { Stand. } \\
\text { Coef. } \\
\text { Beta }\end{array}$} & \multirow[b]{2}{*}{$\mathrm{t}$} & \multirow[b]{2}{*}{ sig } & \multicolumn{2}{|c|}{$\begin{array}{l}\text { Collinearity } \\
\text { Statistics }\end{array}$} \\
\hline & B & $\begin{array}{l}\text { Std. } \\
\text { Error }\end{array}$ & & & & Tollerence & VIF \\
\hline (Constant) & $-27,118$ & 75,128 & &,- 361 &, 721 & & \\
\hline $\mathrm{CR}$ & ,683 &, 178 & ,564 & 3,845 & ,001 & ,999 & 1,001 \\
\hline EPS &,- 787 & ,390 &,- 296 & $-2,017$ & 053, & ,999 & 1,001 \\
\hline
\end{tabular}

a. Dependent Variable: HS

Tabel di atas menunjukan hasil pengujian multikolinieritas data. Dari data yang disajikan bahwa variabel Current Ratio (X1) memiliki nilai tolerance sebesar 0,999, variabel Earning Per Share (X2) memiliki nilai tolerance sebesar 0,999, sehingga dapat diartikan bahwa semua variabel memiliki nilai tolerance lebih besar dari 0,10.

Kemudian bahwa variabel Current Ratio (X1) memiliki nilai VIF sebesar 1,001, variabel Earning Per Share (X2) memiliki nilai tolerance sebesar 1,001, sehingga dapat diartikan bahwa semua variabel memiliki nilai VIF lebih kecil dari 10,00 (VIF < 10,00). Maka dapat disimpulkan bahwa pada penelitian ini tidak terjadi multikolinieritas.

\subsubsection{Uji Heteroskedastisitas Coefficients $^{\mathrm{a}}$}

\begin{tabular}{|c|l|l|c|c|}
\hline Model & $\begin{array}{l}\text { Undstandardized } \\
\text { Coefficients }\end{array}$ & $\mathrm{T}$ & sig \\
\hline
\end{tabular}




\begin{tabular}{|l|r|r|l|r|}
\cline { 4 - 5 } & & \multicolumn{1}{|c|}{$\begin{array}{l}\text { Std. } \\
\text { E }\end{array}$} & $\begin{array}{l}\text { Standardized } \\
\text { Coefficients } \\
\text { Beta }\end{array}$ & \\
\hline 1 & 8,664 &, 817 & & 10,599 \\
\hline CR &,- 001 &, 002 &,- 076 &,- 402 \\
\hline EPS &,- 001 &, 004 &,- 054 &,- 287 \\
\hline
\end{tabular}

a. Dependent Variable: LnRes_2

Berdasarkan tabel di atas diperoleh informasi bahwa nilai Sig. yang diperoleh kedua variabel bebas lebih besar dari 0,05. Hal ini menunjukan bahwa varians residual dari satu pengamatan ke pengamatan lain bersifat homokedastisitas.

\subsubsection{Uji Autokolerasi} Model Summary ${ }^{b}$

\begin{tabular}{|c|c|c|r|c|c|}
\hline $\begin{array}{c}\text { Mode } \\
1\end{array}$ & $\mathrm{R}$ & $\begin{array}{c}\text { Squar } \\
\mathrm{e}\end{array}$ & $\begin{array}{c}\text { Adjuste } \\
\mathrm{d} \mathrm{R} \\
\text { Square }\end{array}$ & $\begin{array}{c}\text { Std. Error } \\
\text { of the } \\
\text { estimate }\end{array}$ & $\begin{array}{c}\text { Durbin } \\
- \\
\text { Watso } \\
\mathrm{n}\end{array}$ \\
\hline 1 & $\begin{array}{r}630 \\
\mathrm{a}\end{array}$ &, 397 &, 354 & $\begin{array}{r}202,297,22 \\
3\end{array}$ & 1,795 \\
\hline
\end{tabular}

a. Predictors: (Constans), EPS, CR

b. Dependen Variabel: HS

Dari tabel di atas bahwa besarnya

nilai Durbin-Waston adalah 1,795.

Dalam ketentuan yang telah dijelaskan

di atas, jika nilai D-W diantara -2 sampai +2 maka penelitian ini tidak terdapat autokolerasi.

\subsection{Uji Regresi Berganda}

\section{Coefficients $^{\mathrm{a}}$}

\begin{tabular}{|c|c|c|c|c|c|}
\hline \multirow[b]{2}{*}{ Model } & \multicolumn{2}{|c|}{$\begin{array}{l}\text { Undstandardized } \\
\text { Coefficients }\end{array}$} & \multirow{2}{*}{$\begin{array}{l}\text { Standa } \\
\text { rdized } \\
\text { Coeffi } \\
\text { cients } \\
\text { Beta } \\
\end{array}$} & \multirow[b]{2}{*}{$\mathrm{t}$} & \multirow[b]{2}{*}{ sig } \\
\hline & B & $\begin{array}{l}\text { Std. } \\
\text { Error }\end{array}$ & & & \\
\hline 1 (Constant) & $-27,118$ & 75,128 & &,- 361 &, 721 \\
\hline CR & ,683 & ,178 &, 564 & 3,845 & ,001 \\
\hline EPS &,- 787 & ,390 &,- 296 & $-2,017$ & ,053 \\
\hline
\end{tabular}

a. Dependen Variabel: HS

Berdasarkan tabel di atas diperoleh persamaan sebagi berikut:

$$
\mathrm{Y}=-27,118+0,683 \mathrm{X} 1-0,787 \mathrm{X} 2
$$

Dari hasil persamaan regresi linier berganda tersebut masing-masing variabel dapat diinterpretasikan sebagai berikut:

a. Konstanta (a)
Nilai a $=-27,118$. Dengan arah hubungan negative menunjukan jika Current Ratio (X1) dan Earning Per Share (\$2) bernilai nol (0), maka nilai keontungan (Y) sebesar nilai konstan (a) ,yatitu sebesar -27,118.

\section{b. Nilai X1}

Nilai X1 sebesar 0,683 memiliki nilai koefisien regresi positif, hal ini menunjukan bahwa Current Ratio mengalami peningkatan maka mengakibatkan naiknya Harga Saham sebesar 0,683 atau $68,3 \%$.

c. Nilai $\mathrm{X} 2$

Nilai X2 sebesar $-0,787$ memiliki nilai koefisien regresi negatif, hal ini menunjukan bahwa apabila Earning Per Share naik, maka Harga Saham naik sebesar $78,7 \%$.

\subsection{Uji Hipotesis}

\subsubsection{Uji Koefisien Determinasi} Model Summary

\begin{tabular}{|r|c|r|r|c|r|}
\hline Model & $\mathrm{R}$ & $\begin{array}{c}\mathrm{R} \\
\text { Square }\end{array}$ & $\begin{array}{c}\text { Adjusted } \\
\mathrm{R} \\
\text { Square }\end{array}$ & $\begin{array}{c}\text { Std. Error } \\
\text { of the } \\
\text { estimate }\end{array}$ & $\begin{array}{c}\text { Durbin- } \\
\text { Watson }\end{array}$ \\
\hline 1 &, $630^{\mathrm{a}}$ &, 397 &, 354 & $202,297,223$ & 1,795 \\
\hline
\end{tabular}

a. Predictors: (Constans), EPS, CR

Berdasarkan tabel di atas, besarnya Adjusted Square $\left(\mathrm{R}^{2}\right)$ adalah 0,354 atau $35,4 \%$. Hal ini menunjukan bahwa variabel yang diteliti variabel Current ratio (X1) dan Earning Per Share (X2) berpengaruh sebesar $35,4 \%$ terhadap harga saham. Sedangkan sisanya $64,6 \%$ (100\% - 35,4\%) dipengaruhi oleh variabel lain yang tidak diteliti dalam penelitian ini.

\subsubsection{Uji t}

\begin{tabular}{|l|r|r|r|r|r|}
\hline \multirow{2}{*}{ Model } & \multicolumn{2}{|c|}{$\begin{array}{l}\text { Undstandardized } \\
\text { Coefficients }\end{array}$} & $\begin{array}{l}\text { Stand. } \\
\text { Coeff } \\
\text { Beta }\end{array}$ & & \\
\cline { 2 - 6 } & B & \multicolumn{1}{c|}{$\begin{array}{c}\text { Std. } \\
\text { Error }\end{array}$} & & t & sig \\
\hline 1 (Constant) & $-27,118$ & 75,128 & &,- 361 &, 721 \\
\hline CR &, 683 &, 178 &, 564 & 3,845 &, 001 \\
\hline EPS &,- 787 &, 390 &,- 296 & - &, 053 \\
\hline
\end{tabular}


a. Dependen Variabel: HS

b.

1. Current Ratio $\left(\mathrm{X}_{1}\right)$ memiliki $\mathrm{t}_{\text {hitung }}$ sebesar 3,845 $>t_{\text {tabel }} 2,04523$ dan nilai signifikansi 0,001 dimana nilai signifikansi $0,001<0,05$. Diartikan bahwa $\mathrm{H}_{1}$ diterima yang berarti bahwa nilai Current Ratio secara parsial berpengaruh signifikan terhadap Harga Saham.
2. Earning Per Share $\left(\mathrm{X}_{2}\right)$ memiliki thitung sebesar $-2,017<\mathrm{t}_{\text {tabel }} 2,04523$ dan nilai signifikansi 0,053 dimana nilai signifikansi $0,053>0,05$. Diartikan bahwa $\mathrm{H}_{1}$ ditolak yang berarti nilai Earning Per Share secara parsial tidak berpengaruh signifikan terhadap Harga Saham.

\subsubsection{Uji f}

\begin{tabular}{|c|c|c|c|c|c|}
\hline \multicolumn{6}{|c|}{ ANOVA $^{a}$} \\
\hline Model & $\begin{array}{c}\text { Sum of } \\
\text { Squares }\end{array}$ & Df & $\begin{array}{l}\text { Mean } \\
\text { Square }\end{array}$ & $\mathrm{F}$ & Sig \\
\hline 1Regression & $755,827,743$ & 2 & $\begin{array}{r}3 \\
77,913,871\end{array}$ & 9,234 &, $001^{\mathrm{b}}$ \\
\hline Residual & $1,145,876,664$ & 28 & $40,924,167$ & & \\
\hline Total & $1,901,704,407$ & 30 & & & \\
\hline
\end{tabular}

a. Dependen Variabel: HS

b. Predictors: (Constans), EPS, CR

Perhitungan yang dapat dilihat pada tabel di atas menunjukan bahwa diketahui nilai $F_{\text {hitung }} 9,234>F_{\text {tabel }} 3,32$ diperoleh nilai Sig Uji F sebesar 0,001 < 0,05 maka dapat di interpretasikan bahwa Current Ratio (X1) dan Earning Per Share (X2) secara bersama- sama (simultan) berpengarun terhadap Harga Saham (Y).

\section{KESIMPULAN DAN SARAN 5.1 Kesimpulan}

Berdasarkan hasil penelitian data dan pembahasan yang telah dilakukan pada bab sebelumnya, maka dapat ditarik kesimpulan dari penilitian ini mengenai Pengaruh Current Ratio dan Earning Per Share terhadap Harga Saham pada perusahaan Subsektor Farmasi yang terdaftar di Bursa Efek Indonesia perode 2015-2018 dengan 8 sampel perusahaan adalah sebagai berikut:

Adanya pengaruh yang signifikan Current Ratio terhadap harga saham pada perusahaan Subsektor Farmasi yang terdaftar di Bursa Efek Indonesia. Hal ini sejalan dengan hasil penelitian yang dilakukan oleh (Wilda, Kardinal, \& Elisabeth, 2015), yang menyatakan bahwa Current Ratio memiliki perngaruh yang signifikan terhadap harga saham.

Tidak adanya pengaruh Earning Per Share terhadap harga saham pada perusahaan Subsektor Farmasi yang terdaftar di Bursa Efek Indonesia. Hal ini sejalan dengan hasil penelitian yang dilakukan oleh (Rahmadewi \& Abudanti, 2018), yang menyatakan bahwa Earning Per Share tidak mempunyai perngaruh terhadap harga saham.

Ada pengaruh signifikan Current Ratio dan Earning Per Share secara bersama- sama terhadap Harga Saham pada perusahaan Subsektor Farmasi yang terdaftar di Bursa Efek Indonesia. Hal ini sejalan dengan hasil penelitian yang dilakukan (Rahmadewi \& Abudanti, 2018), yang menyatakan bahwa Current Ratio dan Earning Per Share secara 
bersama- sama mempengaruhi Harga Saham.

\subsection{Saran}

Berdasarkan dengan penelitian yang dilakukan, peneliti memberikan saran sebagai berikut:

1. Penelitian dilakukan berdasarkan hanya pada perusahaan farmasi yang terdaftar di Bursa Efek Indonesia. Sehingga hal ini tidak bisa digeneralisasikan untuk seluruh perusahaan yang terdaftar di BEI. Maka untuk peneliti berikutnya disarankan untuk menggunakan sampel lain dengan sector yang berbeda dan memperpanjang periode pengamatan guna untuk mendapatkan jumlah sampel yang lebih baik.

2. Penelitian ini hanya menggunakan dua variabel independen. Untuk itu, pada penelitian selanjutnya diharapkan dapat menambah variabel independen lainya yang mempengaruhi nilai perusahan, menggunakan factor terkait lainnya.

3. Bagi perusahaan, disarankan agar lebih meningkatkan Current Ratio perusahaan karena jika Current Ratio meningkat maka akan menarik banyak investor untuk menanamkan modal di perusahaan sehingga harga saham akan ikut meningkat.

\section{DAFTAR PUSTAKA}

Darmadji, Tjiptono, \& Fakhrudidin. (2016). Pasar Modal di Indonesia . Jakarta: Salemba Empat.

Fahmi, F. (2016). Pengantar Manajemen Keuangan.

Bandung: ALFABETA.

Ghozali, G. (2018). Aplikasi Analisis Multivariats dengan Program SPSS . Semarang: Badan Penerbit Universitas Diponegoro.

Hartono, H. (2016). Teori Portofolio dan Analisi Investasi. Yogyakarta: Edisi Kesepuluh.
Kasmir, K. (2015). Analisis Laporan Keuangan. Jakarta: Raja Grafindo Persada.

Mahmud, M. (2016). Analisis Laporan Keuangan. Yogyakarta: UPP STIM YKPN.

Martalena, \& Maya Melinda. (2015). Pengantar Pasar Modal. yogyakarta: Andi .

Martani, D. (2016). Akuntansi Keuangan Menengah. Salemba Empat.

Rahmadewi, \& Abudanti. (2018). Pengaruh EPS, PER, CR, dan ROE terhadap Harga Saham.

Rahmadewi, P. W., \& Abudanti, N. (2018). Pengaruh EPS, PER, CR, dan ROE terhadap Harga Saham di BEI TAHUN 2012-2016. Business Management.

Rochaety, E., Tresnati, R., \& Latief, A. M. (2019). Metodologi Penelitian Bisnis dengan Aplikasi SPSS. Jakarta: Mitra Wacana Media.

Sudana, S. (2018). Manajemen Keuangan Perusahaan Teori dan Praktek. Jakarta: Erlangga.

Sugiyono, S. (2015). Metode Penelitian Kuantitatif Kualitatif dan $R \& D$. Bandung: Alfabeta.

Sujarweni, S. (2016). Kupas Tuntas Penelitian Akuntansi dengan SPSS. Solo: Pustaka Baru.

Sutrisno, S. (2016). Manajemen Keuangan Teori Kosep \& Aplikasi. Yogyakarta: Ekonisia.

Widodo, A., \& Dewi, R. P. (2017). Pengaruh CR, DER dan EPS terhadap Harga Saham. Business Management.

Wilda, Kardinal, \& Elisabeth, S. M. (2015). Pengaruh ROE, CR, dan EPS terhadap Harga Saham Perusahaan Makanan dan Minuman yang terdaftar di Bursa Efek Indonesia (BEI) tahun 20132016. Business Management. 